\title{
Integrative Thematic Teaching Materials Based on Local Wisdom
}

\author{
${ }^{1}$ Asih Mardati, ${ }^{2}$ Hanum Hanifa Sukma \\ ${ }^{1}$ hanum.sukma@gmail.com \\ ${ }^{1,2}$ Primary School Teacher Education, Faculty of Teacher Training and Education, Ahmad Dahlan \\ University
}

\begin{abstract}
Integrative thematic teaching material based on local wisdom as an effort to improve elementary school students' social interaction, cultivating the concept of social interaction based on the students' local wisdom in the learning process. The method was Research and Development (R \& D). The development was carried out referring to the ADDIE development model with 5 phases: Analaysis, Design, Development, Implementation, and Evaluation. The research subject was fourth grade students. The results of the material and learning expert's assessment indicate that the integrative thematic teaching material based on local wisdom is suitable to be used, in which has the criteria of "very good". Media expert's assessment result indicate that the integrative thematic teaching material based on local wisdom is suitable to be used, in which has the criteria of "very good". The results of this study are expected to contribute to the development of integrated thematic teaching material products in elementary schools that can be used to enhance students' social interaction by promoting local wisdom.
\end{abstract}

Keywords: teaching material, integrative thematic, social interaction, local wisdom

\section{INTRODUCTION}

Education is complex, starting from the primary education level, secondary education, to higher education. Primary education has a strategic position in cultivating moral values in order to build a generation who have superior quality, tough, and has strong character[1].

Curriculum changes that occur time to time bringing the main jobs for educators to follow the pattern of the era so that the learning process is in accordance with what is needed. One effort to realize it is by integrated learning so that it can be vary, in which one of them is thematic learning[2]. stated that thematic learning model allow students, both individually and in groups, to actively search, excavate, explore, and discover concepts and principles that are holistic, authentic, and sustainable.

Educators and prospective educators should develop teaching materials that can helping students to understand the concepts, and also complementing learning resources for students. In Government Regulation number 19 of 2005 Article 20, it is implied that educators are expected to develop teaching material, which is then confirmed through the Minister of National Education Regulation (Permendiknas) number 41 of 2007 concerning Standard Process, which among others regulates the planning of learning processes that require educators in education unit to develop Rencana Pelaksanaan Pembelajaran/RPP (Lesson Plan). One element in RPP is a learning resource. Therefore, educators are expected to be able to develop teaching materials as a source of learning. Learning resources that has been developed is in the form of integrative thematic teaching material based on local wisdom. 
Learning with the local wisdom approach means linking learning with the initial knowledge that has been possessed, linking learning with the students' environmental situation, and motivating students by providing learning activities and tasks related to life in their surrounding environment. Sumarmi and Amiruddin (2014) [3] explained that local wisdom is a local knowledge that is used by local communities to survive in an environment. It is integrating with the system of beliefs, norms, laws, culture, and expressed in traditions and myths that are held for a long time. In general, local wisdom has the following characteristics and functions: (1) as an identity marker of the community; (2) as an adhesive element of social cohesion; (3) as an element of culture that grows from the bottom, exists and develops in society; not an element that is forced from above; (4) function to provide a color of togetherness for certain communities; (5) can change the mindset and reciprocity of individuals and groups, by placing it above the common ground; (6) able to encourage the formation of togetherness, appreciation, and a joint mechanism to defend themselves from the possibility of disruption or destruction of group solidarity as a whole and integrated community.

Based on the needs analysis in elementary schools, the social interaction can shape the children's character since elementary school, even pre-school. Character formation cannot be formed instantly, but it can be formed continuously. The students' behavior is mostly influenced by parenting, moral behavior of the people around, and the parenting style of the teachers as the parents at school. Playing with peers is one means to develop the children's ability to interact socially, especially elementary school children who can be said to be agents of change. Agent of change can have a positive or negative impact. This is because the age of elementary school children between 6-12 years is a time when children can determine right and wrong. In order to make children as agents of change, treatment is needed that can lead the children to a positive goal.

Based on the above thoughts, the teachers should be able to combine learning by integrating local wisdom. One way is to develop integrative thematic teaching material based on local wisdom. Teaching material is a set of materials that are systematically arranged, both written and unwritten, so as to create an atmosphere that allows students to learn[4]. Interesting teaching materials that in accordance with the students' characteristics will create an environment or atmosphere that allows students to learn. Starting from these thoughts, learning in elementary schools requires proper teaching materials in facing the 2013 curriculum based on thematic-integrative.

The importance of research on the development of integrative thematic teaching material based on local wisdom is that it is expected to improve elementary school students' social interaction. Therefore, by local wisdom, students can develop personality, cultural identity of the community in the form of values, norms, ethics, beliefs, customs, and special rules that has set abilities so that it can survive continuously. In principle, local wisdom is a good value, a cultural advantage of the local community, and related to the geographical conditions broadly. Therefore, the nature of such local wisdom, it will reflect local cultural conditions. Students will be able to better explain and explore local wisdom if they are more familiar with surrounding culture.

\section{THEMATIC LEARNING BASED ON LOCAL WISDOM}

Meaningful and joyful thematic learning can be realized by linking learning material with the students' closest world or commonly known as contextual teaching and learning. To contextualize thematic learning, it can be done through the cultivation of local wisdom values from students' environment. This is useful for maintaining and preserving local culture, while 
helping students to face growing challenges. It is hoped that education can achieve meaningful learning with principle of think globally, act locally[5].

Local wisdom is knowledge, practice, and trust that develops through an adaptation process that is passed on from generation to generation through culture, the relationship between living things (including humans), and the surrounding environment[6]. Local knowledge can be conveyed in stories, songs, cultural values, beliefs, rituals, customary law, and regional languages. Local wisdom is a cultural product of the past that deserves to be constantly used as a guide in life. Although local values but the values contained in it is considered very universal. In terms of culture, comprehensively can be observed from cultural values that include aspects of: (1) Religious-spiritual, (2) Moral, (3) Society, (4) Customs and traditions, (5) Education and knowledge, (6) Technology, (7) Spatial planning and architecture, (8) Livelihoods, (9) Arts, (10) Languages, (11) Cultural heritage objects and cultural heritage areas, (12) Leadership and government, (13) Fight and nationality, and (14) A distinctive spirit of Yogyakarta. The fourteen aspects can be further elaborated in detail into the value points.

\section{METHOD}

The type of research was Research and Development (R \& D). The development was carried out referring to the ADDIE development model[7]. consisting of Analysis, Design, Development, Implementation and Evaluation.

Development procedures were carried out through the following phases.

1. Preliminary studies (presurvey),

At this phase was done need analysis to develop product. The analysis included curriculum analysis, analysis on learning resources, and analysis on the students' characteristics. From the analysis, it was intended to meet the criteria of teaching materials must be interesting and can help students to achieve competencies.

2. Planning

The planning phase was carried out based on the things obtained from the analysis phase. Activities carried out at the planning phase were: arranging the draft of teaching materials and instruments. In general, the teaching materials contain titles, learning instructions, competencies to be achieved, supporting information, tasks, learning activities to improve social interaction, and work steps and evaluation/assessment.

3. Development of the draft product or initial product

The development phase included the preparation of teaching materials. After determining the framework of teaching materials preparation, the next phase was to determine the product of teaching materials. Teaching materials prepared pay attention to the following quality requirements; a) Aspects of Content Feasibility; b) Linguistic Aspects c) Presentation Aspects and d) Aspects of local wisdom. Teaching materials that have been developed were then tested for validity. Validity test results were used as a reference for the improvement of the product before product testing.

4. Implementation

At this phase, the integrative thematic teaching materials would be piloted for fourth grade students.

5. Evaluation

This phase was carried out to revise teaching material based on input from experts 


\section{DISCUSSION}

Needs Analysis Based on the results of observations and interviews with fourth grade students of Muhammadiyah Pakem Elementary School, several facts were found on the field, including lack of social interaction that made children reluctant to talk with their friends, only to remain silent in class during break time. This is because students are not accustomed to interaction with others because one of the habits carried out at home is using gadget. It causes children to be insensitive towards surrounding environment.

\section{Analysis of Integrative Thematic Teaching Materials}

\section{Core Competencies of $4^{\text {th }}$ grade}

1. Accepting and carrying out the religion they adheres to.

2. Demonstrating honesty, discipline, responsibility, polite, caring and confident behavior when interacting with family, friends, teachers, and neighbors.

3. Understanding factual knowledge by observing (hearing, seeing, reading) and asking based on curiosity about themselves, God's creatures and activities, and the objects they encounter at home and school.

4. Presenting factual knowledge in clear, systematic, and logical language, in aesthetic work, in movements that reflect healthy children, and in actions that reflect the children's faithful and noble behavior.

By taking the Kompetensi Inti/KI (core competencies) mentioned above, which include Core Competencies (KI)-I and KI-II of $4^{\text {th }}$ grade elementary school, the teachers are expected to be able to give reinforcement to support the formation of positive attitudes, knowledge, and behavior. This is stated to provide habituation, model example, and culture in the school. The development of creative ideas in choosing learning methods can also be included in the selection of KI I and KI II. Various learning strategies that will be developed (for example students play roles, observe, ask questions, tell stories, sing, and draw), in addition to involving students directly, it is expected to involve school residents and the school environment. Teachers can develop: (a) Active, Creative, Effective, and Fun (PAKEM) learning methods, (b) questioning skills that oriented to high-level thinking skills, (c) skills in opening and closing learning, and (d) classroom management skills. The map of basic competency based on the KI mentioned above is:

\section{Core Competencies Mapping}

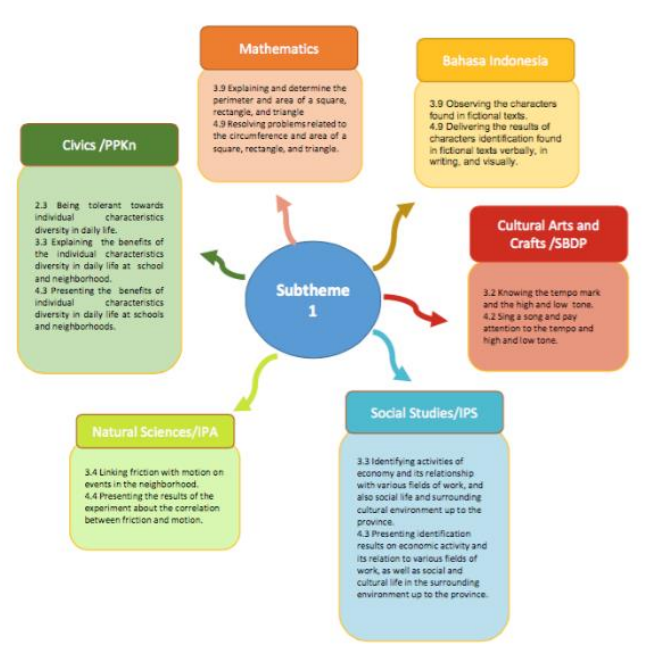

Contents of Integrative Thematic Teaching Material

Theme: Theme 8 (My Residence Area)

Subtheme

1. Subtheme 1: My Living Environment

2. Subtheme 2: Uniqueness of My Residential Area

3. Subtheme 3: Proud on My Residential Area

Evaluation: Literacy and Project-Based Activities 


\section{Experts' Validation}

1. . Learning Expert

- Add assistance information on teaching materials

- Choose simple words and sentences in making questions

2. Language Expert

- Choose commonly used terms

- Reduce the language that cause multiple interpretations

- Detailing the instructions in order to be clear on how to use the teaching materials

3. Media Expert

- The color emphasis on the pictures need to be brighter

- Use several colors for the alphabets to attract students

- Use one large bag for the teaching aid to make it easy to carry

After receiving input from experts, the researchers made several improvements, i.e. choosing words and sentences that were simple for the questions, applying attractive colors in the pictures, selecting the right words so as not to cause double interpretation.

\section{CONCLUSION}

The development of integrative thematic teaching material based on local wisdom for $4^{\text {th }}$ grade students was prepared by applying the development model of ADDIE (Analysis, Design, Development, Implementation \& Evaluation). Analysis phase included curriculum analysis, analysis on students' characteristics, and instructional analysis. The design phase was carried out with the preparation of teaching materials. In the development phase, the development of a module draft was carried out with aspects that have been determined, then followed by experts' validation. Validation from media expert, language and learning expert provided input on teaching materials, and then done a revision.

\section{REFERENCES}

[1] N. A. D. A. M. Estuwardani, "Pengembangan Bahan Ajar Modul Tematik-Integratif Dalam Peningkatan Karakter Peserta Didik Kelas I Sekolah Dasar," J. Pendidik. Karakter, vol. 5, no. 2, 2015.

[2] Rusman, Model-Model Pembelajaran Mengembangkan Profesionalisme Guru. Jakarta: Rajawali Pers, 2011.

[3] S. \& Amiruddin, Pengelolaan Lingkungan Berbasis Kearifan Lokal. Yogyakarta: Aditya Medai Publishing, 2014.

[4] Depdiknas, Panduan Pengembangan Bahan Ajar. Jakarta: Direktorat Jendral Pendidikan Dasar Dan Menengah, 2008.

[5] U. D. Unga, "Pembelajaran Tematik Berbasis Kearifan Lokal Di Sekolah Dasar Dalam Menghadapi Masyarakat Ekonomi Asean (Mea)," J. Teor. Dan Praksis Pembelajaran Ips, vol. 1, no. 1, 2016.

[6] Dahliani, "Local Wisdom In Built Environment In Globalization Era," Int. J. Educ. Res., vol. 3, no. 6, pp. 158-159, 2015.

[7] P. A. Benny, Model Design System Pembelajaran. Jakarta: Dian Rakyat, 2009. 